IZA DP No. 6477

Police and Crime: Evidence from Dictated Delays in Centralized Police Hiring

Paolo Buonanno

Giovanni Mastrobuoni

April 2012 


\title{
Police and Crime: Evidence from Dictated Delays in Centralized Police Hiring
}

\author{
Paolo Buonanno \\ University of Bergamo \\ and Collegio Carlo Alberto \\ Giovanni Mastrobuoni \\ Collegio Carlo Alberto, CeRP \\ and IZA \\ Discussion Paper No. 6477 \\ April 2012 \\ IZA \\ P.O. Box 7240 \\ 53072 Bonn \\ Germany \\ Phone: +49-228-3894-0 \\ Fax: +49-228-3894-180 \\ E-mail: iza@iza.org
}

\begin{abstract}
Any opinions expressed here are those of the author(s) and not those of IZA. Research published in this series may include views on policy, but the institute itself takes no institutional policy positions.

The Institute for the Study of Labor (IZA) in Bonn is a local and virtual international research center and a place of communication between science, politics and business. IZA is an independent nonprofit organization supported by Deutsche Post Foundation. The center is associated with the University of Bonn and offers a stimulating research environment through its international network, workshops and conferences, data service, project support, research visits and doctoral program. IZA engages in (i) original and internationally competitive research in all fields of labor economics, (ii) development of policy concepts, and (iii) dissemination of research results and concepts to the interested public.
\end{abstract}

IZA Discussion Papers often represent preliminary work and are circulated to encourage discussion. Citation of such a paper should account for its provisional character. A revised version may be available directly from the author. 


\begin{abstract}
Police and Crime:

Evidence from Dictated Delays in Centralized Police Hiring*

This paper exploits dictated delays in local police hiring by a centralized national authority to break the simultaneity between police and crime. In Italy police officers can only be hired through lengthy national public contests which the Parliament, the President, and the Court of Auditors need to approve. Typically it takes three years before the requested police officers are recruited and become operational. We show that this endogeneity vanishes once, controlling for countrywide year effects, we use positive changes in the number of police officers. The availability of data on two police forces, specialized in fighting different crimes, provides convincing counterfactual evidence on the robustness of our results. Despite the inefficient hiring system, regular Italian police forces seem to be as efficient in fighting crimes as the US ones, with two notable exceptions: auto thefts and burglaries.
\end{abstract}

JEL Classification: $\quad \mathrm{H} 7, \mathrm{H} 72, \mathrm{H} 76$

Keywords: police, crime

Corresponding author:

Giovanni Mastrobuoni

Collegio Carlo Alberto

Via Real Collegio 30

Moncalieri (TO), 10024

Italy

E-mail: giovanni.mastrobuoni@carloalberto.org

\footnotetext{
* We would like to thank Paolo Pinotti, Aleksey Tetenov and seminar participants at the AL CAPONE $1^{\text {st }}$ Annual Meeting (Rio de Janeiro) and CESifo Workshop on the Economics of Crime for many useful comments and suggestions. Any opinions expressed here are those of the authors and not those of the Collegio Carlo Alberto
} 


\section{Introduction}

In this paper we investigate the empirical relationship between police and crime across Italian regions over the period 1980-1997. Our identification strategy is based on a centralized police hiring procedure, which is widely different from the decentralized U.S. one. In the US it is estimated that around $2 / 3$ of police officers are hired and work in local police departments (Skogan and Kathleen Frydl, 2004). In Italy the central government decides how many police officers need to be hired, and the procedures needed introduce some important delays between the hiring decisions and the actual hiring. We exploit these documented delays in a nationwide centralized hiring system of police forces to estimate their deterrent effect on crime breaking the simultaneity between police and crime. In the years considered in our analysis every police officer was hired through a centralized public contest (concorso pubblico). The parliament would sign a law establishing the total number of allowed hirings, over the following 2 to 3 years. In section 3 we document that it would take at least 2 years, and more often 3 years, before these hirings were implemented.

These centralized hiring methods generate sharp increases in the number of police officers across time and across regions. We provide evidence that most of the endogeneity works at the national level. Adding year fixed effects, which captures countrywide changes in police that are driven by national changes in crime, moves the elasticity from positive to negative. But even within a centralized hiring system the distribution of police forces on the ground might depend on regional trends in crime. This is where we exploit the delays: we show that consistently with the documented long delays only distant changes in crime predict current changes in police forces. Conditioning on year fixed effects, positive changes in police that are driven by the centralized hiring procedures would be endogenous only if local changes in crime rates were predictable 3 years in advance. But we show that controlling for local expectations using flexible local time trends leaves our 
estimates unchanged.

We also show that unlike positive changes in police, negative ones might not be subject to delays. Retirement rules of police officers, for example, allow for flexible retirement ages 1 The elasticity of total crime with respect to police is indeed asymmetric around 0 : the elasticity is close to 0 for negative changes in police and positive and significantly smaller than 0 for positive changes. The estimated elasticity is around -25 percent once we control for measurement error (Griliches and Hausman, 1986). We also propose a local instrumental variables approach to identify the elasticity at positive thresholds that are not necessary 0 , and the results are robust to using larger thresholds.

In addition to providing an estimated elasticity of crime with respect to police that is based on a new identification strategy, this paper contributes to the literature highlighting the importance of hiring and firing constraints. We present a simple model of optimal police enforcement with adjustment costs, and show that in line with the predictions of the model for the US, the endogeneity bias is more prevalent where the changes in police enforcement are larger, while for Italy it is more prevalent where the changes in police enforcement are negative. Moreover, the model shows how policy makers' expectations on future crime determines the optimal number of police officers, as a function of hiring delays. The final contribution is to provide a first elasticity of crime with respect to police for Italy.

Becker (1968)'s seminal work formalizes the intuition that increased enforcement might deter criminals from committing crimes 2 Given the implied policy implications, over the last 40 years a large body of research has tried to uncover the police-crime relationship. But despite the theoretical unambiguous predictions it has been extremely hard to find convincing empirical evidence about the causal relationship between po-

\footnotetext{
${ }^{1}$ Temporary transfers of police offices to high crime areas are possible but quite rare. Permanent ones are very rare as well, and police offices face several constraint that limit their ability to transfer police officers. More on this later.

${ }^{2}$ Almost two-hundred years earlier Cesare Beccaria had written that certain and severe punishments can deter people from committing crimes (Beccaria, 1786).
} 
lice enforcement and crime. Indeed, several meta-analysis contributions (Cameron, 1988, Marvell and Moody, 1996, Vollaard and Hamed, 2011) reviewed the existing literature finding little or no evidence supporting the idea of a deterrent effect of police force 3 As noted by Marvell and Moody (1996), most research does not appropriately tackle the endogeneity of police enforcement, which biases the estimated effects of police on crime upwards. Policy makers tend to increase police enforcement in areas that experienced higher crime levels, generating a positive correlation between police and crime. This fact is clearly visible for both Italy (left panel) and the US (right panel) in Figure 1, where we plotted the countries' total crime and total police forces over several years.

Only in recent years a growing number of papers started exploiting peculiar features in police hiring procedures, or use quasi-experimental settings in order to determine the causal impact of police on crime. Levitt (1997) uses mayoral elections in 59 major US cities to instrument changes in police enforcement and finds that an increase of $10 \%$ in police forces implied a reduction 3 to $10 \%$ in crime rates 4 He argues that the incumbent may have incentives to increase police in order to publicly show his willingness to reduce crime only for electoral purposes. This is likely to be the case of mayors, since police department are organized at city level. More recently, Evans and Owens (2007) exploit the Community Oriented Policing Services (COPS) program to study its effect on crime. The relevant feature of this program is represented by the fact that the US Department of Justice, through centralized federal grants, covered up to $75 \%$ of the cost for new police officers to local police agencies for crime prevention programs for the period 1994 to 2000 . As a result over 64,000 new police officers were hired at local level. Their estimates are

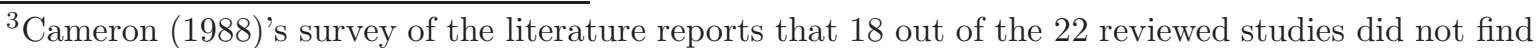
a relationship between police and crime. Marvell and Moodv (1996) report that only 10 studies over the 36 reviewed found a significant inverse relationship between police levels and crime rates. Finally Vollaard and Hamed (2011) find that only 5 estimates out of the 22 reviewed estimates exhibit a negative effect of police on violent crime.

${ }^{4}$ In response to McCrary (2002) who challenged these results due to some coding errors, Levitt (2002) uses the number of fire-fighters and other municipal workers as instruments for the number of police officers and finds evidence of large deterrence effects.
} 
similar to the ones found in Levitt (1997, 2002).

Another strand of literature has tried to solve the reverse causality problem between crime and police relying on small scale experiments or quasi-experiments. Following a quasi- randomized experiment, where different districts in Kansas city received different levels of patrolling Kelling (1974) finds little evidence of deterrent effect of police on crime rates. Di Tella and Schargrodsky (2004), instead, exploit the fact that in the aftermath of the terrorist attacks in Buenos Aires there was an increased police deployment around mosques and temples which generates sudden reductions in crime. Similarly, Draca et al. (2012), exploiting the large and unanticipated redeployment of police officers to central London after the terrorist attacks that hit central London in July 2005, show an elasticity of crime with respect to police of approximately -30 percent 5 Poutvaara and Priks (2009) estimate the causal effect of policing on hooligan violence. They solve the endogeneity issue exploiting police reallocation happened in Sweden for reasons stemming from outside the country: the 9/11 terrorist attack in 2001 and the Tsunami in December 2004. While these papers use clever identifying variations the external validity of their results is ambiguous.

Corman and Mocan (2000) take advantage of the fact that new police officers are required to attend a six-months course at the Police Academy before their effective deployment and use monthly time-series data on crime to circumvent the simultaneity issues. But their estimates, as the ones coming from the more experimental papers, refer to a specific city, while ours, thanks to longer delays, refer to a whole country. Our analysis, like the one in Evans and Owens (2007), relies on a centralized policy intervention, but exploits documented delays between the time the hiring procedures started and the time the newly recruited police officer become operational, as in Corman and Mocan (2000). Italian recruiting procedures have some advantages over the one based on the COPS pro-

\footnotetext{
${ }^{5}$ See also Vollaard and Hamed (2011) who uses British data to estimate the relationship between police and crime.
} 
gram analyzed in Evans and Owens (2007): i) local police offices do not apply to hire more officers; ii) several years pass between the centralized financial decision to increase the number of police forces and the actual hiring, making it less likely that hirings depend on expected changes in crime rates; iii) the relative changes in police forces that are driven by our centralized hiring system tend to be larger.

\section{Model of Police Hiring and Firing}

This section is going to provide a simple model of optimal size of police that is going to help us understand the endogeneity of hiring and firing decisions. The model is not going to allow for police transfers across regions, which is in line with transfers across Italy being rare, and either driven by the police officers' preferences, or just temporary 6 The policy makers' objective function depends on the total amount of crime and police.

They minimize the expected cost of crime and police:

$$
W\left(p_{t}, p_{t+1, . .}\right)=E_{t}\left[\sum_{i=0}^{\infty}(1+\delta)^{-i}\left(c\left(p_{t+i}\right)+k_{H} 1\left(\Delta p_{t+i}>0\right)+k_{F} 1\left(\Delta p_{t+i}<0\right)\right)\right]
$$

where $c\left(p_{t+i}\right)$ represents the total cost of crime and police (wages, cars, etc) as a function of police $p$ in the following period and we assume the function $c(\cdot)$ to be convex. Given that 1 (true) $=1$ in the second part of the expression $k_{H}$ and $k_{F}$ measure "hiring" and "firing" costs, that do not depend on the change in police forces. Assuming that these costs are proportional to the change in police officers the results are qualitatively the same. The discount rate $\delta \leq 1$ captures that policy makers care more about current levels of crime than about future ones.

\footnotetext{
${ }^{6}$ The article 55 of the Presidential decree n. 335 of April 24, 1982 allows only police officers that have reached a tenure of at least four years to request a transfer. In rare occasions, for example sports events, or public demonstrations, police offices use temporary transfers. Permanent transfers are extremely rare and practically speaking only used to transfer police chief officers. The reason is that transferred officers receive for at least two years a significant wage premium, a housing subsidy, and a moving subsidy.
} 
To simplify the expression we are going to use a second order approximation of each $c\left(p_{t+i}\right)$ around the frictionless optimal level of policing $p_{t+i}^{*}$, where $\frac{\partial c\left(p_{t+i}\right)}{\partial p_{t+i}}=0$ and $c^{\prime \prime}\left(p_{t+i}^{*}\right)=k>0$. Equation 1 is therefore approximately equal to a constant that does not depend on the vector $p$ and

$$
E_{t}\left[\sum_{i=0}^{\infty}(1+\delta)^{-i}\left(\frac{k}{2}\left(p_{t+i}-p_{t+i}^{*}\right)^{2}+k_{H} 1\left(\Delta p_{t+i}>0\right)+k_{F} 1\left(\Delta p_{t+i}<0\right)\right)\right]
$$

This function has a very intuitive interpretation: on top of hiring and firing costs there is a loss from having the police that is far from its optimal level.

The optimal plan of policing is obtained by differentiating 2 with respect to each level of police $p_{t+i}$. This problem has no general solution (see Hamermesh and Pfann, 1996), unless one assumes static expectations about $p_{t+i}^{*}$. If the optimal size of police forces depends linearly on crime, this means that $E_{t}\left(p_{t+i}^{*}\right)=E_{t}\left(\alpha c_{t+i}\right)=\alpha c_{t}$. In this case the solution is

$$
\begin{aligned}
& p_{t+i}=\alpha c_{t}, i=0,1, \ldots, \text { if } k_{H} \leq z_{t} \text { and } z_{t}>0 ; \text { or } k_{F} \leq-z_{t} \text { and } z_{t}<0 \\
& p_{t+i}=p_{t-1}, i=0,1, \ldots, \text { otherwise }
\end{aligned}
$$

where $z_{t}=\frac{(1+\delta)}{\delta}\left(p_{t}^{*}-p_{t-1}\right)$.

This solution has again an intuitive interpretation. The level of police depends on the optimal level of police and on how deviation from it introduce hiring or firing costs, both immediately, and in expectation for the future. If the optimal size of police changes because there has been a sudden large change in crime that, given the "random walk" assumption, is believed to persist, then the government will adjust the size of the police forces accordingly. If, instead, those changes and the implied long-term losses $z_{t}$ are not large enough to compensate the hiring or firing costs police forces are not going to 
change from one period to the next. Larger discount rates, and larger costs are thus going to increase the attrition of police forces. Moreover, if hiring costs are extremely large compared to firing costs, like in the Italian case, adjustments when crime increases are less likely than when crime decreases 7

But the Italian case introduces another constraint. Due to administrative burdens the adjustments of police forces when crime changes unexpectedly can only happen after at least three years. In other words, the solution for the Italian case is:

$$
\begin{aligned}
& p_{t+i}=\alpha c_{t}, i=3, \ldots, \text { if } k_{H} \leq z_{t} \text { and } z_{t}>0 ;, \text { or if } i=1, \ldots, \text { if } k_{F} \leq-z_{t} \text { and } z_{t}<0 \\
& p_{t+i}=p_{t-1}, i=0,1, \ldots, \text { otherwise, }
\end{aligned}
$$

where we just added the condition $i>2$ when new police officers should be hired. This means that positive adjustments in police forces happen only after at least 3 years from the time the adjustment was needed.

The next section describes the source of the delays, and shows that changes in police officers happen indeed with a lag of three years.

\section{Mass Hirings}

The 1981 law number 121 rules the present organization of Italy's police forces. There are a total of five police forces: Polizia di Stato, Arma dei Carabinieri 8 Guardia di Finanza, Polizia Penitenziaria and Corpo Forestale dello Stato. They exercise different functions: Polizia di Stato and Carabinieri are responsible for maintaining public security and keeping public order, while Guardia di Finanza, as the name suggests, fights financial or white collar crimes, frauds, and smugglings. Of the remaining two forces, which are

\footnotetext{
${ }^{7}$ Relaxing the assumption on static expectations one can show that adjustments are less likely to occur the smaller is the persistence of crime shocks.

${ }^{8}$ Carabinieri is the shortened (and common) name for the Arma dei Carabinieri
} 
outside our focus, the Polizia Penitenziaria is responsible for security and surveillance in Italian prisons, and the Corpo Forestale dello Stato is the park rangers' force, responsible for protecting Italy's national parks and national forests.

Polizia di Stato is a civil force that depends on the Minister of Interior, while Arma dei Carabinieri is a military force (gendarmerie) that depends on the Minister of Defense. They have identical functions. Historically, Carabinieri was created by King Victor Emmanuel I of Savoy with the aim of providing the Kingdom of Sardinia with a police force. The Polizia di Stato was established in 1852 (they were called Corpo delle Guardie di Pubblica Sicurezza) and subsequently merged to the Carabinieri in 1922. In 1925 the Fascist regime decided that the Ministry of Interior had to oversee the Polizia. It is commonly believed that after World War II policy makers decided to keep the two forces separate so as to make coup d'etats more difficult. For the purpose of our analysis we are going to focus on the Polizia and the Carabinieri but, given their crime specialization, the Guardia di Finanza provides a powerful robustness check.

As briefly discussed in section 1, police officers are hired through nationally centralized public contests 9. The law establishes the procedure that needs to be followed to hire new police officers. This generates a considerable time lag between the time the law gets approved and the time the newly recruited police officers become operational. Let us briefly describe how the procedure works and later provide a specific example to clarify the extent of these delays 10 . Bills need to be discussed in both chambers of the parliament, which typically requires around one year. Once approved, the law needs to be signed by the President of the Republic and, if it needs some funding, to be approved by the Corte dei Conti (the Italian Auditor Court). In order to become effective, the law must be published in the Gazzetta Ufficiale (G.U.). For example, in 1986 the Minister of Interior started the procedure to hire 3,000 police officers. The decree was approved by

\footnotetext{
${ }^{9}$ Hiring procedures were set in 1981 (article 47 and 48 of Law n. 121). This law was later modified in 1982 (Decree Law n. 335) and in 2000 (Decree Law n. 234)

${ }^{10} \mathrm{~A}$ complete list of laws is presented in Table 1
} 
the Corte dei Conti on January 9, 1987 and then published on the G.U. on March 3, 1987. Once published, potential candidates have to apply for the position within one month. The oral and written examinations took place one year later, on February 23 and 24, 1988. On average after six months candidates are notified about the results of the examination. Successful candidates are required to complete a one-year training course (Law n.121/1981). Thus, on average, new police officers become effective 3 years after the approval of the law. This hiring procedure introduces a significant and sizable lag, that allows us to break the simultaneity between police and crime. In addition, in many cases the law itself establishes the year in which new police officers should be hired 11 Moreover, transferring police officers on a permanent basis from one office to another is extremely cumbersome, and can only be requested by the police officers (see footnote 6).

A simple way to test whether such institutional constraints are binding is to regress changes in police on past changes in crime levels. Since contemporaneous changes would also capture the causal effect we are interested in, they cannot be tested. The regressions measure the endogeneity of lagged changes and are run with and without controlling for year fixed effects. Given that Italy's main decision maker in the central government we expect year fixed effects to capture most of the endogeneity of changes in police. Column 1 of Table 4 shows that without fixed effects the second, third, and fourth lag of the change in crime predict current changes in police. The first lag does not. The largest and most significant coefficient is on $c_{t-3}-c_{t-4}$ which is fully consistent with the delays in hirings we documented before. The pattern of the coefficient seems to suggest that there is an inverse U-shaped pattern of endogeneity that lasts between $t-2$ and $t-4$, and peaks at t-3. While being non-testable one would think that since there is no endogeneity at $t-1$ extrapolating from this pattern there shouldn't be any at time $t$. Column 2 shows that even when we don't control for previous lag there is no evidence of endogeneity at $t-1$.

\footnotetext{
${ }^{11}$ For example, Law n. 410/1985 established how many of the 8,800 new Carabinieri had to be hired in each year up until 1989.
} 
The difference in the R-squared between columns 1 and 2 show also that the changes in crime explain a good deal of variation in police.

Column 3 shows that adding year fixed effects annihilates most of the endogeneity of police. All coefficients but the one on $c_{t-3}-c_{t-4}$ stop being significant. The way we interpret this result is that when the government decides to hire new police officers local offices might start lobbying to receive more recruits. But the important result is that year effects capture most of the endogeneity and that the only residual endogeneity seems to be 3 periods away. There might still be endogeneity hidden at time $t$ if police offices respond to changes in crime through retirement strategies. We cannot test for contemporaneous changes but later we are going to show that positive changes in police forces that are driven by centralized hirings show very different elasticities than negative ones.

The next question is whether there is enough variability across time in such hirings. In Table 2 we show the fraction of regions in a given year with changes in police forces that are above or below certain thresholds. The lower thresholds have be chosen to be reasonably large and thus able to capture changes in police staffing that is driven by mass hirings, and large enough to provide a reasonable amount of variation. There are still 6 percent of observations with changes above 10 percent. The first 3 columns of Table 2 show that there is variability both across time and across space in mass hirings, defined as an increase in police forces of at least 0, 5, or 10 percent. 1987 stands out as the year where most regions (100 percent) had a positive increase in the number of police officers. In that same year 63 percent of regions increased the number of police officers by more than 10 percent. Notice that these changes happened three years after the government decree signed on March 1984 and January 1985 (see Table 1), while in 1985 and in 1986 none of the regions show an increase of at least 5 percent. This represent additional evidence that several years pass between the signing of the law and the actual hiring of the recruits. 
We exploit the peculiarities of this hiring system using a balanced, yearly, regional panel for the years for which data on crime and police are available (1980 to 1997). Our main explanatory variable is the total number of Carabinieri and Polizia di Stato force, in short "police force."12 Crime data are taken from the official crime statistics that are recorded by the police and are published yearly by the Italian Statistics Institute (ISTAT) at region level and by type of crime. For the purpose of our analysis we consider: robbery, murder, assault, burglary, car theft, bag snatching, larceny, fraud and smuggling.

We also collected a set of socioeconomic and demographic variables that are usually included in crime regressions. We include the percentage of men aged 15-35. Young men are said to be more prone to engage in criminal activities than the rest of the population (Freeman, 1991, Grogger, 1998). Turning to the socioeconomic variables, we include the (log of) real GDP per capita and the unemployment rate which measure the legitimate and illegitimate earning opportunities (Ehrlich, 1973, Gould et al., 2002, Raphael and Winter-Ember, 2001). We complete our dataset by including education measures: the percentage of population with high school diploma, and the percentage of population with university degree 13 Our list of control variables is likely to be incomplete. In order to control for unobserved factors we exploit the panel structure of our data either differencing the data or including region-specific fixed effects. We also include year dummies in order to adjust for exogenous shocks in crime rates that are common to all regions.

Table 3 presents the summary statistics of the variables used in our analysis. Over the period 1980 to 1997 there were on a yearly basis an average of close to 3,000 crimes per 100,000 inhabitants. More in detail, property crimes account for more than $60 \%$ of total crime, while violent crime represent a small fraction being on average 96 per 100,000

\footnotetext{
${ }^{12}$ These data have been used by Marselli and Vannini (1997), and provided to us by the authors.

${ }^{13}$ Education may have a sort of "civilization" effect reducing crime over and above its effect through labor market opportunities (Buonanno and Leonida, 2009, Fajnzylber et al,, 2002, Lochner and Moretti, 2004).
} 
inhabitants. Police officers are on average 360 every 100,000 inhabitants. To put these data into an international perspective, it is worth noticing that in 1991 Italy had compared to all the other European countries the largest number of officers per capita (1 every 286 citizen), while the US had one officer every 459 citizens Wolff et al. (1992).

\section{Empirical Evidence}

\subsection{Differences between Italy and the US}

In Italy the endogeneity of police is almost entirely driven by nationwide decisions that are taken years in advance, as shown in the previous section. Unlike for the US, where where the endogeneity is mainly local and with shorter delays, this kind of endogeneity can be controlled for without the need of an additional instrument. The intuition is that centralized hiring decisions depend on expectations about the evolution of crime at the national level. This "between" endogeneity is going to be captured by the year fixed effects. But centralized hiring decisions might incorporate the decision about where to deploy the newly recruited police officers, thus generating a "within" endogeneity that would only be captured by year fixed effects interacted with region or city fixed effects. This would be in line with the evidence provided so far (column 3 of Table 4). But, given the sizable delays between the hiring decisions and the effective police officers deployment, the endogeneity vanishes.

This subsection highlights the Italian peculiarities in the decision making process with respect to the U.S. one. The first column of Table 5 shows that controlling for region or city fixed effects regressing the logarithm of total crime rates on the logarithm of the number of police forces per 100,000 inhabitants one gets a positive coefficient in both, Italy (upper panel) and the US (lower panel). This is in line with what we saw in Figure

1. Column 2 shows that simply adding year fixed effects lowers the coefficient for the US, 
most likely because fixed effects capture the endogeneity due to Federal decisions. But the elasticity is still positive and highly significant, indicating that adding year fixed is far from solving the endogeneity. The elasticity for Italy, instead, goes from +50 percent to -24 percent, a total turnaround.

Columns 2 and 3 show that replicating columns 1 and 2 on first-differenced data does not change these findings. Given that the Italian hiring process introduces long delays the positive coefficient must be driven by nationwide expectations on crime. This must be why the coefficient is only significant at the 10 percent level, while the U.S. one is significant at the 1 percent level. Adding year effects flips the sign of the Italian elasticity from positive to negative, while doing little to the U.S. one. The last column shows that adding other region or city-level controls as well as region fixed effects does not change the results for Italy, while it captures some of the endogeneity for the US. Notice that region fixed effects would be equivalent to region level time trends in a fixed effects regressions. They would capture any endogeneity that would be driven by expectations about crime that are linear. This is again in line with the two countries having different levels of decision making.

One can notice that the first-difference estimator is twice smaller than the fixed effects one, for both the US and Italy. All the evidence seems to suggest that these differences between the two estimators are driven by measurement error. Measurement error bias with serially uncorrelated errors is know to be exacerbated when using firstdifferences instead of fixed effects (Griliches and Hausman, 1986). While Levitt (1997, 2002) or Evans and Owens (2007) would have solved the measurement error with the use of an instrument, we don't have a proper instrument. But a an old paper by Griliches and Hausman (1986) shows that one can recover the measurement error bias based on the differences between the two estimators. In a model where (log) police forces $p$ are measured with a classical measurement error $\nu$, they show that the fixed effects 
estimator's and the first-difference estimator's probability limits are

$$
\operatorname{plim} \hat{\beta}_{\Delta}=\beta\left(1-\frac{2 \sigma_{\nu}^{2}}{\sigma_{\Delta p}^{2}}\right) \text { and } \operatorname{plim} \hat{\beta}_{F E}=\beta\left(1-\frac{T-1}{T} \frac{\sigma_{\nu}^{2}}{\sigma_{\tilde{p}}^{2}}\right)
$$

where $\Delta p_{i t}=p_{i t}-p_{i t-1}, \tilde{p}_{i t}=p_{i t}-\bar{p}_{i}$, and $\sigma^{2}$ indicates the variances 14

Solving for $\beta$ one can show that a simple linear combination of the two biased estimators gives a consistent estimator:

$$
\hat{\beta}=\frac{a}{a-b} \hat{\beta}_{F E}+\frac{-b}{a-b} \hat{\beta}_{\Delta}
$$

where $a=2 T \sigma_{\tilde{p}}^{2}$, and $b=(T-1) \sigma_{\Delta p}^{2}$. Given that $a$ is generally larger than $b$, this estimator gives a positive weight that is larger than 1 on the fixed effects estimator and a negative one on the first difference one. Table [6] shows all the ingredients that are needed to compute the signal to noise ratio, which is 89.9 percent. The reason why such a large signal to noise ratio leads to such a large measurement error for the first-difference estimator lies in the large serial correlation in police officers, which lead to considerably lower variability once one first-differences the data. The consistent estimator of the elasticity of crime with respect to police is -26.8 percent, which is not far from the fixed effect estimator. This means that in order to adjust the first-difference estimator for the measurement error one can simply multiply the estimator by two, for both the US and Italy.

To be able exploit discontinuities between positive and negative changes in police from now on we are only going to use specifications in first-differences. Given that all these specifications are prone to the exact same measurement error bias they should all be inflated by the same factor. While we could have presented the corrected estimates we believe that it is more transparent to present the estimates without the correction. This preliminary analyses show that there are differences in the endogeneity between between

\footnotetext{
${ }^{14}$ One can use the Frish-Waugh theorem if there are other regressors that are not measured with error.
} 
crime and police are likely to be driven by very different police hiring procedures. It is clear that yearly changes in crime at the local level lead to larger and more immediate adjustments in police enforcement in the US than they do in Italy. Consistently with our model in the US controlling for city and year fixed effects does not break the simultaneity between crime and police, while the opposite is true in Italy. Given that for Italy we know that only hiring decisions are prone to long delays the next step is to exploit this heterogeneity.

\subsection{Identification based on mass hirings}

We just showed that adding year fixed effects alleviates the endogeneity issue when the hiring system is centralized. But there might still be "within" endogeneity left. In order to exploit the dictated delays we devise a test for whether the whole endogeneity bias has been eliminated. It rests on a comparison between estimates based on positive and negative variations in the number of police officers, knowing that the positive ones are driven by national mass hirings. In column 1 of Table 7 we separately control for positive and negative changes in police forces. A clear discontinuity emerges: positive changes induce a negative and significant elasticity of 13 percent, while negative changes tend to have a positive, but non significant, effect. Notice that the elasticity does not change much when we add other controls (column 2). In column 3 we add a quadratic time trend, which is equivalent to a cubic one in levels. This would make our estimates robust to a fairly flexible region-level pattern of expectations about future crime trends.

Alternatively, a more flexible way to identify elasticities based on thresholds is to use local instrumental variables. The estimation proceeds in two steps. In step 1 we identify the region-year observations that show positive increases in police forces, or increases that are larger than a given threshold, and in step 2 we instrument changes in the $(\log )$ number of police forces with the subset of large increases in the (log) number of police 
forces. We instrument changes in the log number of police officers $\Delta \log P_{r t}$ with just changes above the $\gamma$ threshold, $\Delta \log P_{r t} \times 1\left(\Delta \log P_{r t}>\gamma\right)$, varying $\gamma$. The identification is going to be based on just the changes in police forces that lie above the thresholds. Columns 4 to 9 of Table[7present the local (IV) estimates using three different thresholds: 0, 5, and 10 percent, with and without controlling for other regressors. Notice that while the estimation procedure is equivalent to an instrumental variable regression, the instruments are not proper instruments but are just a device to select the variation in the data one decides to exploit. Notice also that these "pseudo" instruments do not solve the measurement error bias, and the elasticities have to be inflated by a factor of slightly more than two.

The IV estimates are basically identical to the ones based on positive changes in police. This seems to suggest that the discontinuity in the endogeneity is indeed close to 0 changes in police. Section 4.3 is going to use a more semi-parametric procedure to detect the pattern of endogeneity as a function of the change in police.

\subsection{Semi-parametric evidence}

Instead of fixing some thresholds, here we estimate "running elasticities" along the distribution of the changes in police. We start by estimating the elasticities based on just the first 40 percentiles of the changes in police forces 15 These elasticities together with the corresponding (pointwise) 90 percent confidence intervals are shown at the beginning of the two plots shown in Figure 2, one for Italy and one for the US. The left y-axes show the elasticities, while the right ones show the log changes in police. The very first point on the left tells us that around the 20th percentile $( \pm 20 \%)$ the elasticity is close to zero in Italy and close to +20 percent in the US. The corresponding average changes in police forces are slightly larger than $-3 \%$ in Italy and slightly lower than $-4 \%$ in the US. The

\footnotetext{
${ }^{15}$ We chose the 40 percentiles rule to smooth the elasticities.
} 
next point uses the data that lies between the 2 nd and the 41st percentile of the changes in police. The last point, the 80th one uses the data centered around the 80th percentile (percentile 60 to 100).

Several interesting differences emerge between the US and Italy: i) the elasticities tend to be larger in the US than in Italy; ii) in Italy the elasticities tend to be negative for positive changes in police forces (right of the vertical line) and positive for negative changes, which is consistent with the evidence related to mass hirings shown before; iii) in the US the elasticities tend to be small around small changes in police and large when changes in police are large, no matter whether positive or negative. This evidence for both the US and Italy is consistent with our model: with concave hiring and firing costs we would expect positive elasticities when the policy makers decide to opt for large changes (positive or negative) in police staffing (see Equation 2). Moreover, given that in given year positive changes in police for Italy depend on crime levels that reach at least 3 years back, it is not surprising that the elasticities move from positive to negative when the changes in police ar equal to 0 (vertical line). This is in line with the solution shown in Equation 3.

\subsection{Elasticities for different crimes and crime categories}

Analyzing just the total number of crimes that get reported to the police might hide heterogeneity in the elasticities across crime categories. We categorized crimes to render them comparable to the uniform crime reports used in Levitt (1997, 2002), McCrary (2002), and Evans and Owens (2007). Moreover, as discussed in Section 3, Italy has a police force that specializes in fighting frauds, smugglings, financial crimes, and tax evasions. This specialization allows us to see whether these crimes respond to the presence of the financial police and not to the presence of the regular police forces, and viceversa for the non-financial crimes. For this reason Table 8 analyzes "frauds" and "smugglings." We 
also added bag-snatching, a highly visible crime that might respond to increased police patrolling.

Table 8 shows 2SLS estimates using the threshold equal to 0 for many different crimes and controlling for the regressors used in the even numbered columns in Table 7 . Panel $A$ shows the results using as regressors only regular police officers, Panel $B$ using only "financial" police officers, and Panel C using both police forces separately. Let us first start by noting that running the regressions for the two police forces separately or together has little effect on the coefficients 16 The coefficient in the last column corresponds to the sum of all crimes using just the regular police, and is therefore a simple replication of the result shown in column 6 of Table 7. The same column in Panel B shows that the financial police has no significant influence on total crimes. But columns (5) and (6) in Panel $C$ show, not surprisingly, that the Guardia di Finanza has a large negative effect on frauds (-41 percent ) and smugglings (-86 percent). With the exception of assaults, which may be due to patrolling, financial police shows no significant negative effect on the remaining crimes. Some elasticities are even positive, and we have no explanation for this, other than sampling variability.

But let us now move to the regular police. There is clear evidence that the strongest impact are on violent crimes (-25.6 percent). In particular, murders show the largest responsiveness (-80 percent), followed by robberies (-55.7 percent) and assaults (-30.4 percent). These results are similar to the ones found in Levitt (2002) and Evans and Owens (2007) but are likely to be even larger given that one needs to adjust these estimates for measurement error bias. In Evans and Owens (2007) the lowest elasticities are found for robberies (-122 percent), assaults (-91 percent), and murders (-74.5 percent). In Levitt (2002) murders and robbery elasticities, respectively -91.4 percent and -45 percent, are very similar to our results. Some property crimes, instead, seem to respond differently

\footnotetext{
${ }^{16}$ The simple correlation between $\log$ regular police and $\log$ financial police is 95 percent, but once we difference the data the correlation drops to 15 percent.
} 
in the US and in Italy to the presence of police. The elasticity of auto thefts is -85 percent in Evans and Owens (2007) and -170 percent in Levitt (2002), while it is precisely estimated to be 0 in our sample. The only property crime that responds to the presence of regular police is bag-snatching. Larcenies and burglaries show no significant changes when more police is employed, but this result is common to Levitt (2002) and in part to Evans and Owens (2007) (they find a negative and significant elasticity for burglaries, -54 percent, but no effect for larcenies).

Despite the use of a different identification strategy applied to a different country our results are in line with Levitt (2002) and Evans and Owens (2007).

\section{Conclusions}

This paper uses a new identification strategy to provide evidence on the effect police has on crime: it exploits Italy's bureaucratic hiring procedures of state employees, in particular police officers. Positive changes in the number of police officers that are driven by mass hirings following lengthy hiring procedures lead to sizable reductions in crime, especially the more violent ones.

Despite the apparent inefficiencies in the allocation of Italian police forces which persists to these days (the last mass hiring decree happened on June 26, 2008), the estimated elasticities of crimes with respect to regular police officers are in line with the ones found in the US, with two notable exceptions: auto thefts and burglaries.

The evidence leads to another open question that we leave for future research: Do the benefits of centralized hiring (lower risk of nepotism and corruption; internalization of potential spatial spillovers) outweigh the costs related to the hiring delays and the potential inefficient allocation of police forces? 


\section{References}

Cesare Beccaria. Dei Delitti e Delle Pene. 1786.

Gary S. Becker. Crime and punishment: An economic approach. The Journal of Political Economy, 76(2):169-217, 1968.

Paolo Buonanno and Leone Leonida. Non-market effects of education on crime: Evidence from italian regions. Economics of Education Review, 28(1):11-17, February 2009.

Samuel Cameron. The economics of crime deterrence: A survey of theory and evidence. Kyklos, 41(2):301-23, 1988.

Hope Corman and Naci H. Mocan. A time-series analysis of crime, deterrence, and drug abuse in new york city. American Economic Review, 90(3):584-604, June 2000.

Rafael Di Tella and Ernesto Schargrodsky. Do police reduce crime? Estimates using the allocation of police forces after a terrorist attack. The American Economic Review, 94 (1):115-133, 2004 .

Mirko Draca, Stephen Machin, and Robert Witt. Panic on the streets of london: Police, crime and the july 2005 terror attacks. American Economic Review, forthcoming, 2012.

Isaac Ehrlich. Participation in illegitimate activities: A theoretical and empirical investigation. Journal of Political Economy, 81(3):521-65, 1973.

William N. Evans and Emily G. Owens. COPS and Crime. Journal of Public Economics, 91(1-2):181-201, 2007.

Pablo Fajnzylber, Daniel Lederman, and Norman Loayza. What causes violent crime? European Economic Review, 46(7):1323-1357, July 2002.

Richard B. Freeman. Crime and the employment of disadvantaged youths. NBER Working Paper No. 3875, 1991. 
Eric D. Gould, Bruce A. Weinberg, and David B. Mustard. Crime rates and local labor market opportunities in the united states: 1979-1997. Review of Economics and Statistics, 84(1):45-61, 2002.

Zvi Griliches and Jerry A. Hausman. Errors in variables in panel data. Journal of Econometrics, 31(1):93-118, 1986.

Jeff Grogger. Market wages and youth crime. Journal of Labor Economics, 16(4):756-91, 1998.

Daniel S. Hamermesh and Gerard A. Pfann. Adjustment costs in factor demand. Journal of Economic Literature, 34(3):1264-1292, September 1996.

George L. Kelling. The kansas city preventive patrol experiment: A summary report. Police Foundation (Washington D.C.), 1974.

Steven D. Levitt. Using electoral cycles in police hiring to estimate the effect of police on crime. American Economic Review, 87(3):270-90, June 1997.

Steven D. Levitt. Using electoral cycles in police hiring to estimate the effects of police on crime: Reply. American Economic Review, 92(4):1244-1250, September 2002.

Lance Lochner and Enrico Moretti. The effect of education on crime: Evidence from prison inmates, arrests, and self-reports. American Economic Review, 94(1):155-189, March 2004.

Riccardo Marselli and Marco Vannini. Estimating a crime equation in the presence of organized crime: Evidence from italy. International Review of Law and Economics, 17 (1):89-113, March 1997.

Thomas B. Marvell and Carlisle E. Moody. Specification problems, police levels, and crime rates. Criminology, 34(4):609-646, 1996. 
Justin McCrary. Using electoral cycles in police hiring to estimate the effect of police on crime: Comment. American Economic Review, 92(4):1236-1243, 2002.

Panu Poutvaara and Mikael Priks. The effect of police intelligence on group violence: Evidence from reassignments in sweden. Journal of Public Economics, 93(3-4):403411, April 2009.

Steven Raphael and Rudolf Winter-Ember. Identifying the effect of unemployment on crime. Journal of Law \& Economics, 44(1):259-83, 2001.

Wesley Skogan and editors Kathleen Frydl. Fairness and Effectiveness in Policing: The Evidence. The National Academies Press, 2004. ISBN 9780309084338.

Ben Vollaard and Joe Hamed. Why the police have an effect on violent crime after all. Evidence from the British Crime Survey. mimeo, Tilburg University, 2011.

Michael Wolff, Peter Rutten, and Albert F. Bayers III. Where we stand: can America make it in the global race for wealth, health, and happiness? 1992. 

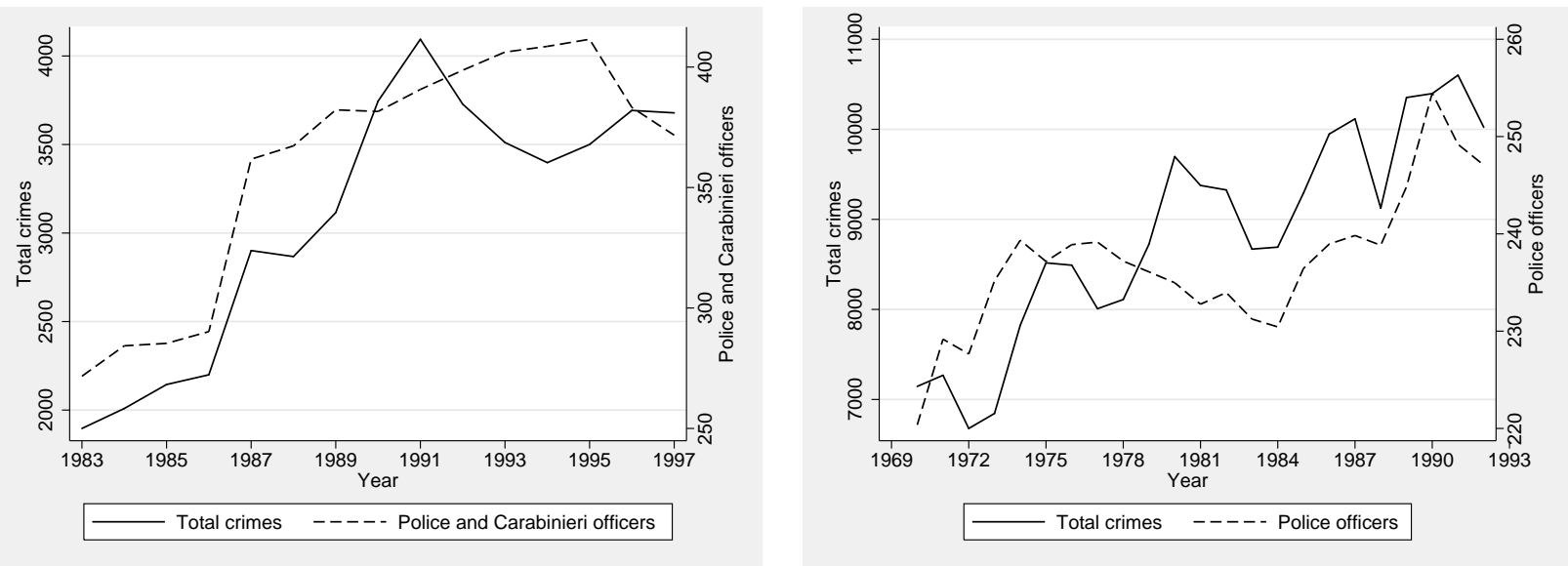

Figure 1: Crime and Police in Italy (left panel) and in the USA (right panel). Source: for Italy ISTAT Statistiche Giudiziarie Penali 1983-1997, for the USA Levitt (1997). 

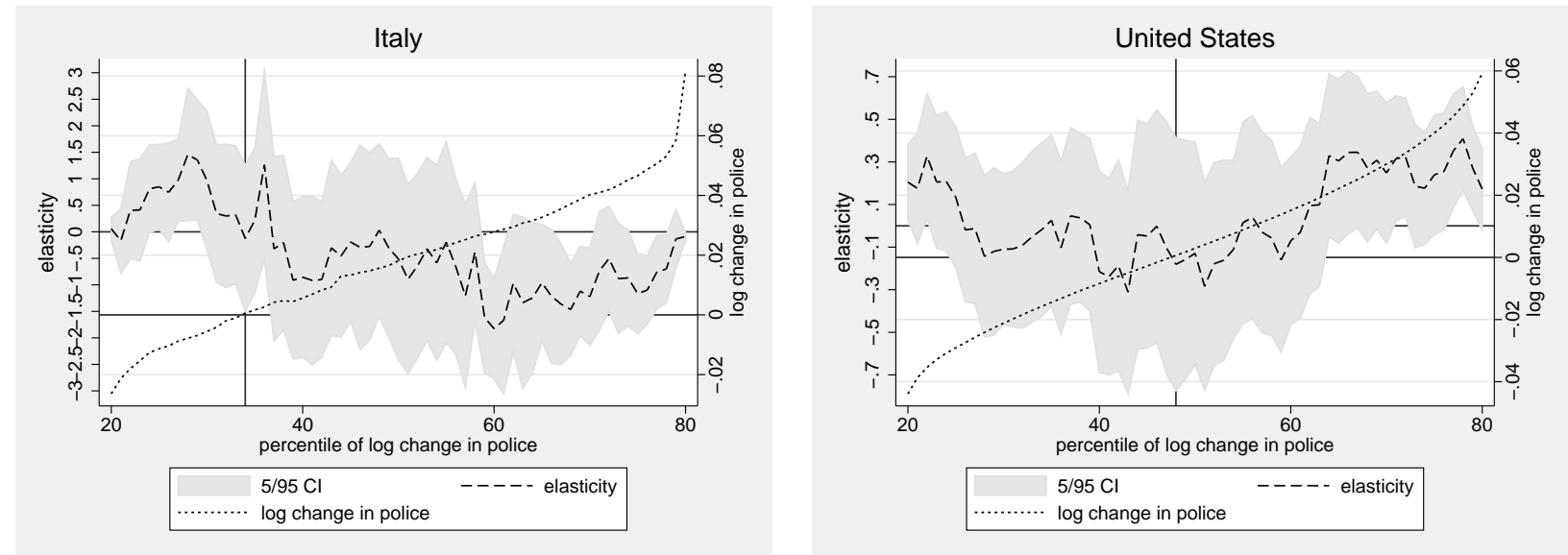

Figure 2: Estimated elasticities across different log changes in police. The vertical line corresponds to a change in police that is equal to 0 .

Source: ISTAT Statistiche Giudiziarie Penali 1983-1997 and McCrary (2002). 
Table 1: Police Force and Carabinieri Recruiting Laws

\begin{tabular}{|c|c|}
\hline$\overline{\mathrm{Law}}$ & Contents \\
\hline Law. n. 121/1981 & $\begin{array}{l}\text { Set hiring procedures (art. } 47 \text { and } \\
48 \text { of Law n. 121). This law } \\
\text { was later modified in } 1982 \text { (De- } \\
\text { cree Law n. 335) and in } 2000 \text { (De- } \\
\text { cree Law n. 234) }\end{array}$ \\
\hline $\begin{array}{l}\text { DPCM (Decreto Pres- } \\
\text { idente Consiglio dei } \\
\text { Ministri) March 2, } \\
1984\end{array}$ & $\begin{array}{l}\text { Recruiting procedure for } 5,000 \\
\text { Carabinieri }\end{array}$ \\
\hline $\begin{array}{l}\text { DPCM January 21, } \\
1985\end{array}$ & $\begin{array}{l}\text { Recruiting procedure for } 6,700 \\
\text { Carabinieri }\end{array}$ \\
\hline Law n.150/1985 & $\begin{array}{l}\text { Recruiting procedure for } 5,206 \\
\text { Police Officers }(2,000 \text { in } 1985 \text {, } \\
1,500 \text { in } 1986 \text { and } 1,000 \text { in } 1987)\end{array}$ \\
\hline Law n. $410 / 1985$ & $\begin{array}{l}\text { Recruiting procedure for } 8,800 \\
\text { Carabinieri }(1,500 \text { in } 1985,1,500 \\
\text { in } 1986,1,500 \text { in } 1987,1,500 \text { in } \\
1988 \text { and } 1,800 \text { in } 1989)\end{array}$ \\
\hline $\begin{array}{l}\text { Minister of Interior } \\
\text { November } 10,1986\end{array}$ & $\begin{array}{l}\text { Recruiting procedure for } 3,000 \\
\text { Police Officers }\end{array}$ \\
\hline Decree Law n. 9/1992 & $\begin{array}{l}\text { Recruiting procedure for } 3,799 \\
\text { Police Officers (in } 1993 \text { and 1994) }\end{array}$ \\
\hline
\end{tabular}


Table 2: Changes in Police Forces

\begin{tabular}{lccccccc}
\hline \multirow{2}{*}{ Regions with changes } & \multicolumn{3}{c}{ larger than } & & \multicolumn{3}{c}{ smaller than } \\
\cline { 2 - 3 } \cline { 7 - 9 } & $0 \%$ & $5 \%$ & $10 \%$ & & $0 \%$ & $-3 \%$ & $-6 \%$ \\
\hline 1983 & 0.00 & 0.00 & 0.00 & & 0.00 & 0.00 & 0.00 \\
1984 & 0.89 & 0.37 & 0.05 & & 0.11 & 0.05 & 0.00 \\
1985 & 0.53 & 0.05 & 0.00 & & 0.47 & 0.05 & 0.05 \\
1986 & 0.68 & 0.11 & 0.00 & & 0.32 & 0.05 & 0.00 \\
1987 & 1.00 & 0.84 & 0.63 & & 0.00 & 0.00 & 0.00 \\
1988 & 0.84 & 0.26 & 0.11 & & 0.16 & 0.11 & 0.11 \\
1989 & 0.89 & 0.21 & 0.00 & & 0.11 & 0.00 & 0.00 \\
1990 & 0.58 & 0.05 & 0.00 & & 0.42 & 0.11 & 0.05 \\
1991 & 0.74 & 0.32 & 0.00 & & 0.26 & 0.00 & 0.00 \\
1992 & 0.89 & 0.05 & 0.00 & & 0.11 & 0.05 & 0.00 \\
1993 & 0.74 & 0.16 & 0.05 & & 0.26 & 0.11 & 0.00 \\
1994 & 0.47 & 0.11 & 0.00 & & 0.53 & 0.05 & 0.00 \\
1995 & 0.53 & 0.11 & 0.00 & & 0.47 & 0.00 & 0.00 \\
1996 & 0.11 & 0.00 & 0.00 & & 0.89 & 0.58 & 0.47 \\
1997 & 0.05 & 0.00 & 0.00 & & 0.95 & 0.42 & 0.05 \\
\hline total & 0.60 & 0.18 & 0.06 & & 0.34 & 0.11 & 0.05 \\
\hline
\end{tabular}

Notes: The table shows the fraction of regions in a given year with changes in police forces that are above or below certain thresholds.

Table 3: Summary Statistics

\begin{tabular}{lccccc}
\hline variable & obs & mean & std.dev. & min & max \\
\hline Police officers & 285 & 359.67 & 132.82 & 86.87 & 750.40 \\
Financial police officers & 285 & 101.41 & 61.86 & 25.77 & 278.68 \\
& & & & & \\
Population & 285 & $3,014.29$ & $2,211.196$ & 330 & 8,974 \\
Fraction pop. aged 15-35 & 285 & .325 & .019 & .28 & .36 \\
Percentage of population with high school diploma & 285 & .17 & .04 & .08 & .27 \\
Percentage of population with university degree & 285 & .04 & .01 & .02 & .08 \\
Gross domestic product & 285 & 14.13 & 3.68 & 7.49 & 21.97 \\
Unemployment rate & 285 & 9.22 & 3.98 & 3.19 & 23.48 \\
& & & & & \\
Total crimes per 100,000 inh. & 285 & $3,098.77$ & $1,318.66$ & $1,031.57$ & $7,709.80$ \\
Property Crimes & 285 & 1880.72 & 888.36 & 394.68 & $4,823.08$ \\
$\quad$ Burglary & 285 & 281.11 & 120.84 & 62.05 & 743.11 \\
$\quad$ Autotheft & 285 & 323.50 & 263.92 & 43.11 & $1,174.16$ \\
$\quad$ Bag snatching & 285 & 203.95 & 184.78 & 6.29 & $1,072.83$ \\
$\quad$ Larceny & 285 & 901.22 & 519.72 & 141.29 & $3,005.91$ \\
Fraud & 285 & 53.88 & 27.83 & 7.21 & 206.01 \\
$\quad$ Smuggling & 285 & 30.28 & 84.10 & 0.00 & 667.14 \\
Violent Crimes per 100,000 inh. & 285 & 95.55 & 37.71 & 38.64 & 243.27 \\
Robbery & 285 & 35.61 & 35.88 & 3.28 & 186.83 \\
Murder & 285 & 1.87 & 2.19 & 0 & 15.18 \\
Assault & 285 & 36.52 & 15.67 & 10.88 & 90.42 \\
Rape & 285 & 1.61 & .70 & .30 & 4.99 \\
\hline
\end{tabular}


Table 4: Endogeneity tests

\begin{tabular}{|c|c|c|c|c|}
\hline & $(1)$ & $\begin{array}{c}(2) \\
\Delta \log \mathrm{p}\end{array}$ & $\begin{array}{c}(3) \\
\text { officers }\end{array}$ & (4) \\
\hline$\Delta \log$ total crime $(t-1)$ & $\begin{array}{c}0.020 \\
(0.037)\end{array}$ & $\begin{array}{c}-0.054 \\
(0.069)\end{array}$ & $\begin{array}{c}0.026 \\
(0.032)\end{array}$ & $\begin{array}{c}-0.089 \\
(0.091)\end{array}$ \\
\hline$\Delta \log$ total crime $(t-2)$ & $\begin{array}{c}0.083^{*} \\
(0.044)\end{array}$ & & $\begin{array}{c}0.021 \\
(0.053)\end{array}$ & \\
\hline$\Delta \log$ total crime $(t-3)$ & $\begin{array}{c}0.099 * * * \\
(0.017)\end{array}$ & & $\begin{array}{c}0.094^{* * *} \\
(0.033)\end{array}$ & \\
\hline$\Delta \log$ total crime $(t-4)$ & $\begin{array}{c}0.086^{* * *} \\
(0.029)\end{array}$ & & $\begin{array}{c}-0.070 \\
(0.097)\end{array}$ & \\
\hline$\Delta \log$ total crime $(t-5)$ & $\begin{array}{c}0.045 \\
(0.030)\end{array}$ & & $\begin{array}{c}0.018 \\
(0.039)\end{array}$ & \\
\hline$\Delta \log$ total crime $(t-6)$ & $\begin{array}{l}-0.020 \\
(0.047)\end{array}$ & & $\begin{array}{l}-0.030 \\
(0.045)\end{array}$ & \\
\hline Year fixed effects & & & $\sqrt{ }$ & $\sqrt{ }$ \\
\hline Observations & 152 & 247 & 152 & 247 \\
\hline R-squared & 0.293 & 0.050 & 0.462 & 0.324 \\
\hline
\end{tabular}


Table 5: Police and Crime in Italy and the US

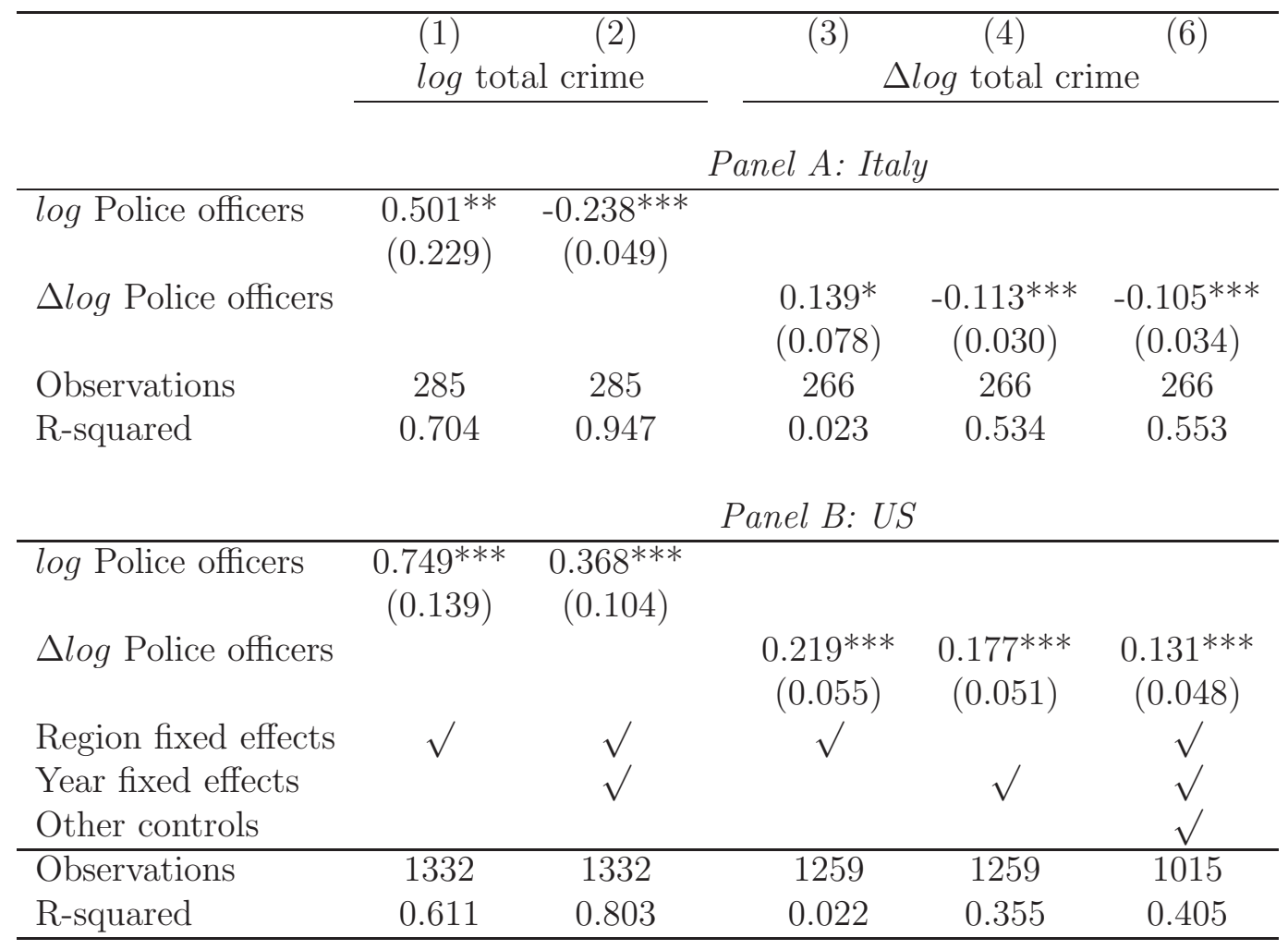

Notes: Regressions are estimated using ordinary least squares. For Italy the additional controls are: \% males aged 15-35, (log of ) real GDP per capita, unemployment rate, \% population with high school and university degree. For the USA the controls are: \% of population aged 15-29, (log of) real income per capita, unemployment rate at state level, share of blacks at city level and public welfare and education spending per capita. Clustered (by region or by city) standard errors in parentheses: ${ }^{* * *} \mathrm{p}<0.01,{ }^{* *} \mathrm{p}<0.05,{ }^{*} \mathrm{p}<0.1$. 
Table 6: Police and Crime in Italy and the US

\begin{tabular}{lc}
\hline Statistic & Value \\
\hline$\widehat{\beta}_{F E}$ & -0.238 \\
$\widehat{\beta}_{\Delta}$ & -0.113 \\
$\sigma_{\nu}^{2}$ & 0.003 \\
$\sigma_{\tilde{x}}^{2}$ & 0.032 \\
$\sigma_{\Delta x}^{2}$ & 0.013 \\
$\mathrm{~T}$ & 285 \\
$\widehat{\beta}_{F E} / \widehat{\beta}_{\Delta}$ & 2.076 \\
Signal to noise ratio & 0.898 \\
$\widehat{\beta}$ & -0.268 \\
\hline
\end{tabular}

Notes: These numbers are based on columns 2 and 4 of Table 5 , and assume serially uncorrelated measurement errors. 
Table 7: Instrumental variables regressions

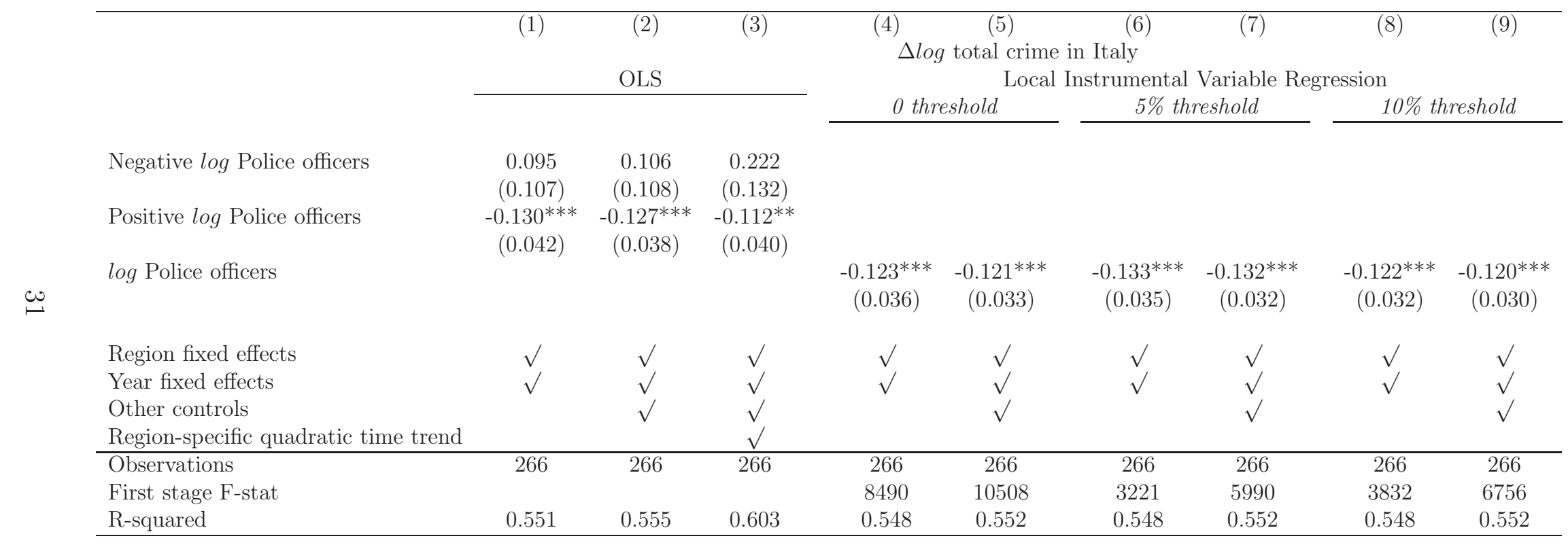

Notes: IV regressions are estimated using two stage least squares. Changes in the log number of police officers $\Delta$ log $P_{r t}$ are instrumented with changes above a given threshold $\gamma \Delta \log P_{r t} \times 1\left(\Delta \log P_{r t}>\gamma\right)$. Clustered (by region) standard errors in parentheses: $* * * \mathrm{p}<0.01, * * \mathrm{p}<0.05, *$ $\mathrm{p}<0.1$. 
Table 8: Instrumental variables regressions for different crime categories

\begin{tabular}{|c|c|c|c|c|c|c|c|c|c|c|c|c|}
\hline \multicolumn{12}{|c|}{$\begin{array}{l}\text { Burglary Auto thert Bag-snatcning Larceny Fraud Smugging Economic } \\
\text { Panel A: Police officers only }\end{array}$} & $\begin{array}{l}(12) \\
\text { Total }\end{array}$ \\
\hline$\Delta \log$ Police officers & $\begin{array}{l}-0.057 \\
(0.053)\end{array}$ & $\begin{array}{c}0.048 \\
(0.083)\end{array}$ & $\begin{array}{c}-0.357^{* * * *} \\
(0.073)\end{array}$ & $\begin{array}{c}0.028 \\
(0.033)\end{array}$ & $\begin{array}{l}0.210 \\
(0.254)\end{array}$ & $\begin{array}{l}0.583^{* *} \\
(0.257)\end{array}$ & $\begin{array}{l}-0.017 \\
(0.040)\end{array}$ & $\begin{array}{c}-0.539^{* * *} \\
(0.163)\end{array}$ & $\begin{array}{l}-0.780^{*} \\
(0.452)\end{array}$ & $\begin{array}{c}-0.328^{* * *} \\
(0.067)\end{array}$ & $\begin{array}{c}-0.258^{* * *} \\
(0.061)\end{array}$ & $\begin{array}{c}-0.121^{* * * *} \\
(0.033)\end{array}$ \\
\hline R-squared & 0.262 & 0.446 & 0.243 & 0.470 & 0.137 & 0.245 & 0.528 & 0.296 & 0.096 & 0.135 & 0.224 & 0.552 \\
\hline \multicolumn{13}{|c|}{ Panel B: Financial police officers only } \\
\hline$\Delta \log$ Financial police officers & $\begin{array}{l}-0.054 \\
(0.067)\end{array}$ & $\begin{array}{c}0.137^{* *} \\
(0.059)\end{array}$ & $\begin{array}{c}0.063 \\
(0.109)\end{array}$ & $\begin{array}{c}0.059 \\
(0.050)\end{array}$ & $\begin{array}{l}-0.376^{*} \\
(0.216)\end{array}$ & $\begin{array}{c}-0.769^{* *} \\
(0.301)\end{array}$ & $\begin{array}{l}0.069^{*} \\
(0.042)\end{array}$ & $\begin{array}{c}0.107 \\
(0.080)\end{array}$ & $\begin{array}{c}0.091 \\
(0.258)\end{array}$ & $\begin{array}{c}-0.300^{* * * *} \\
(0.076)\end{array}$ & $\begin{array}{l}-0.052 \\
(0.059)\end{array}$ & $\begin{array}{l}-0.047 \\
(0.049)\end{array}$ \\
\hline R-squared & 0.260 & 0.449 & 0.198 & 0.473 & 0.147 & 0.227 & 0.530 & 0.253 & 0.083 & 0.140 & 0.200 & 0.543 \\
\hline \multicolumn{13}{|c|}{ Panel C: Police officers and financial police officers } \\
\hline $\begin{array}{l}\Delta \log \text { Police officers } \\
\Delta \log \text { Financial police officers }\end{array}$ & $\begin{array}{l}-0.052 \\
(0.054) \\
-0.047 \\
(0.065)\end{array}$ & $\begin{array}{c}0.035 \\
(0.084) \\
0.132^{* *} \\
(0.058)\end{array}$ & $\begin{array}{c}-0.368^{* * *} \\
(0.074) \\
0.115 \\
(0.100)\end{array}$ & $\begin{array}{c}0.023 \\
(0.032) \\
0.056 \\
(0.051)\end{array}$ & $\begin{array}{c}0.249 \\
(0.258) \\
-0.411^{*} \\
(0.213)\end{array}$ & $\begin{array}{c}0.666^{* *} \\
(0.261) \\
-0.863^{* * *} \\
(0.309)\end{array}$ & $\begin{array}{l}-0.024 \\
(0.040) \\
0.073^{*} \\
(0.040)\end{array}$ & $\begin{array}{c}-0.557^{* * *} \\
(0.166) \\
0.185^{* *} \\
(0.083)\end{array}$ & $\begin{array}{c}-0.801^{*} \\
(0.463) \\
0.205 \\
(0.240)\end{array}$ & $\begin{array}{c}-0.304^{* * *} \\
(0.068) \\
-0.257^{* * *} \\
(0.069)\end{array}$ & $\begin{array}{c}-0.256^{* * *} \\
(0.060) \\
-0.016 \\
(0.056)\end{array}$ & $\begin{array}{c}-0.118^{* * *} \\
(0.032) \\
-0.030 \\
(0.043)\end{array}$ \\
\hline $\begin{array}{l}\text { Observations } \\
\text { R-squared }\end{array}$ & $\begin{array}{c}266 \\
0.262\end{array}$ & $\begin{array}{c}266 \\
0.450\end{array}$ & $\begin{array}{c}266 \\
0.241\end{array}$ & $\begin{array}{c}266 \\
0.472\end{array}$ & $\begin{array}{c}266 \\
0.155\end{array}$ & $\begin{array}{c}264 \\
0.234\end{array}$ & $\begin{array}{c}266 \\
0.531\end{array}$ & $\begin{array}{c}266 \\
0.294\end{array}$ & $\begin{array}{c}264 \\
0.095\end{array}$ & $\begin{array}{c}266 \\
0.156\end{array}$ & $\begin{array}{c}266 \\
0.224\end{array}$ & $\begin{array}{c}266 \\
0.552\end{array}$ \\
\hline
\end{tabular}

Notes: IV regressions are estimated using two stage least squares. Changes in the $\log$ number of police officers $\Delta \log P_{r t}$ are instrumented with changes above 0 . Clustered (by region) standard errors in parentheses: *** $\mathrm{p}<0.01,{ }^{* *} \mathrm{p}<0.05,{ }^{*} \mathrm{p}<0.1$. 